\title{
Sociaal werk in stadswijken waar problemen zich opstapelen
}

\author{
Saskia Welschen \& Lex Veldboer ${ }^{*}$
}

\section{Sociaal werk in de slipstream van stedelijke ontwikkelingen}

De bevolking groeit, de economische groei lijkt niet te stoppen, en de werkloosheid is gedaald naar een ongekend laag niveau (Gemeente Amsterdam, 2018a). In veel opzichten gaat het dus goed met de stad Amsterdam. Tegelijkertijd worden de verschillen in welzijnsniveau tussen gebieden binnen en buiten de ring A10 groter (Gemeente Amsterdam, 2015). Hoewel de segregatie in internationaal perspectief nog relatief bescheiden is, is de trend dat door het strikter toewijzen van goedkope woningen aan de laagste inkomensgroepen, de inkomenssegregatie verder gaat toenemen. Boomtown Amsterdam is daarmee op weg naar een nieuwe ongelijkheid (Boterman \& Van Gent, 2015). Wat betekenen de huidige snelle veranderingen in de bevolkingssamenstelling en de opkomende nieuwe ongelijkheid voor sociaal werk? Het is immers typisch een professie in de slipstream van stedelijke ontwikkelingen. De oprichting van de eerste opleidingen voor sociaal werk eind negentiende eeuw was bijvoorbeeld een antwoord op de snelle verstedelijking en de zeer slechte behuizing van de arbeidersbevolking in binnensteden (Veldboer, 2018). En ook in volgende fasen speelden vraagstukken rond de stedelijke bevolking steeds een prominente rol. ${ }^{1}$ Daarom is het relevant te verkennen wat de huidige sociaalgeografische signalen over 'residualisering' en de daarmee gepaard gaande waarschuwingen voor een nieuwe 'urban crisis' (Florida, 2017) ${ }^{2}$ betekenen voor het welzijnswerk. ${ }^{3}$

In dit artikel bespreken we de consequenties van de ruimtelijke uitsortering ten gevolge van ontwikkelingen op de woningmarkt voor de opdracht van sociaal werk in de stad. We kijken daarbij naar de aard en de impact van de brede residualiseringsopgave op sociaal werk.

Ontwikkelingen op de woningmarkt in Amsterdam zijn ook nu onomstotelijk een belangrijke bepaler van de activiteiten en de locatie van sociaal werk. We zien bijvoorbeeld in de wijken buiten de ring en Noord een sterke stapeling van voorzieningen op grond van de Wet maatschappelijke ondersteuning, zoals hulp in de huishouding, vervoersvoorzieningen, dagbesteding en dagopvang (Gemeente Amsterdam, 2018a, 216). Met uitzondering van het sterk vergrijzende Buitenveldert en delen van Amsterdam-Noord zijn het gebieden waar de sociale huurvoorraad nog een groot deel van de woningmarkt omvat en waar geen of weinig gentrification plaatsvindt. In deze wijken bedient de krimpende sociale corporatiesector in toenemende mate de laagste inkomens. Vrijkomende goedkope woningen worden 'passend' toegewezen aan lage inkomensgroepen (www.platform31.nl).

* Dr. Saskia Welschen is senior onderzoeker aan de Hogeschool van Amsterdam en zelfstandig onderzoeker. Dr. Lex Veldboer is lector aan de Hogeschool van Amsterdam. 
Een flink deel van de vrijkomende goedkope woningen wordt bovendien expliciet toegewezen aan bijzondere doelgroepen met veel zorgvragen en nauwelijks verbinding tot de arbeidsmarkt. Het aantal bewoners in de sociale huurvoorraad met (licht) verstandelijke of lichamelijke beperkingen of psychiatrische problematiek neemt toe. Daarmee versmalt sociale huisvesting steeds meer tot een sector voor huishoudens met een (langdurig) laag inkomen en weinig mogelijkheden om daar iets aan te veranderen (Gemeente Amsterdam, 2017b, 6). In de internationale literatuur wordt dit omschreven met de term residualisering. Hiervan is sprake bij een significante toename van de concentratie van 'seriously disadvantaged households' in complexen van sociale huisvesting en wanneer blijkt dat deze bewoners gedurende de tijd steeds minder bronnen van inkomsten en opleiding hebben (Jacobs e.a., 2010; Andersson \& Turner, 2014).

Niet alleen in de zorgstatistieken maar ook in sociaal-demografische studies zien we deze tendens tot concentratie terug. Hochstenbach en Musterd (te verschijnen) laten zien dat terwijl in centrale delen van de stad het aandeel lage inkomens daalde, dit in de periferie van Amsterdam juist toenam. Zij spreken van een decentralisatie van armoede (naar de randen van de stad). Uit de monitoring van Bureau Onderzoek, Informatie en Statistiek van de gemeente Amsterdam komt eveneens duidelijk naar voren dat minimahuishoudens zich concentreren in bepaalde delen van de stad, met een zwaartepunt in de perifere gebieden in Noord, Zuidoost en Nieuw-West (Gemeente Amsterdam, 2018b). Een recente studie van RIGO combineert beide informatiebronnen (zorg en wonen) en laat zien dat de populatie in corporatiewoningen kwetsbaarder wordt en dat in samenhang daarmee de problematiek op individueel en op collectief niveau toeneemt (RIGO, 2018). Dat uit zich volgens de onderzoekers bijvoorbeeld in een toenemende schuldenproblematiek, overlast van buren en buurtgenoten, verslavings- en gedragsproblematiek en een afname van de leefbaarheid en de sociale cohesie.

De zorgen over de afnemende leefbaarheid door residualisering zijn zeker niet exclusief Nederlands. Een Australische studie naar residualisering in sociale huurgebieden wijst erop dat de komst van nieuwe kwetsbare buren voor zittende bewoners met een lange woonduur vaak een toename van burenoverlast betekent en een daling van de kwaliteit van leven met zich brengt. De directe woonomgeving wordt minder voorspelbaar en wordt daardoor als minder veilig ervaren. Ouderen in de sociale huurwijken van de Australische stad Sydney hechten bijvoorbeeld extra aan community centers, die voor hen fungeren als een 'home away from home' waar ze onder elkaar kunnen zijn. Zij hopen dat door goede begeleiding de nieuwe 'moeilijke' buren zich ontwikkelen tot 'acceptabele buren' (Morris, 2015).

Aan de hand van een literatuurstudie en op basis van een startende casestudie in Geuzenveld bespreken we in dit artikel de consequenties van de ruimtelijke uitsortering ten gevolge van ontwikkelingen op de woningmarkt voor de opdracht van sociaal werk in de stad. We kijken naar de impact op sociaal werk van de brede residualiseringsopgave die zowel door passend toewijzen van sociale huurwoningen als door de vermaatschappelijking in de zorg ontstaat. 


\section{Residualiseringsopgaven voor sociaal werk}

Residualisering stelt het sociaal werk voor nieuwe opgaven, zoals werken aan nieuwe vormen van begeleiding en samenleven. Deze 'residualiseringsopgaven' zijn enerzijds het gevolg van de nieuwe regels op de sociale woningmarkt omtrent passend toewijzen aan inkomensgroepen, maar ze zijn tegelijkertijd ook niet los te zien van andere meer sociale opgaven. De vermaatschappelijking in de zorg (waarbij mensen die voorheen werden opgevangen in instellingen voor bijvoorbeeld geestelijke gezondheidszorg of dakloosheid nu in toenemende mate doorstromen naar een zelfstandige woning) en de instroom van statushouders maken ook onderdeel uit van de residualiseringsopgave. Residualisering vindt namelijk niet alleen haar uitdrukking in de woningmarkt. Het gaat volgens de bekende socioloog Esping-Andersen om een liberaal welvaartsmodel dat ook andere vormen van publieke voorzieningen betreft, zoals uitkeringen of medische ondersteuning. Kern is steeds dat basisvoorzieningen niet universeel beschikbaar zijn, maar slechts openstaan c.q. passend zijn voor de doelgroep van meest behoeftigen (Esping-Andersen, 1990). Dat volgens veel professionals de nieuwe bewoners van aandachtswijken vaak zowel arm zijn als een zorglabel hebben, is dus geen toevallige samenloop, maar onderdeel van een samenhangende ontwikkeling. ${ }^{4}$

Een groei van problematiek in een gebied betekent in dit liberale model dan ook niet vanzelfsprekend een navenante groei in sociaal werk. Vanuit dezelfde passendheidslogica waar corporaties mee worstelen, mogen sociaal werkers in hun werk ook alleen de meest behoeftigen ondersteunen. Strikte toewijzing is hierbij een van de terugkerend kenmerken. ${ }^{5}$ Door de invoering van de nieuwe Wet maatschappelijke ondersteuning (2015) is ondersteuning geven aan mensen in kwetsbare posities bijvoorbeeld beperkter geworden, en de nadruk is bovendien deels verschoven van ondersteuning geven naar het samen met vrijwilligers stimuleren van zelfredzaamheid en actief burgerschap.

In 2014 verwoordden Engbersen en Engbersen $(2014,7)$ hun verwachtingen over de sociale opgave als volgt:

'Het gaat stiller worden in de instituties van de verzorgingsstaat en het wordt drukker in de straten en de portieken waar meer kwetsbare groepen - ouderen, werklozen, mensen met een handicap - aan huis gebonden zijn. (...) Mensen zullen, vaak met verlies van inkomsten én verlies van ondersteuning vanuit zorg en welzijn, meer op zichzelf en elkaar aangewezen zijn. De druk op het samenleven (...) gaat toenemen.'

Vanuit dit enigszins bezorgde startpunt is het tegelijkertijd goed te beseffen dat wijken en buurten in Nederlandse steden zoals Amsterdam voortdurend in beweging zijn; er is als gevolg van het Nederlandse woningmarktbeleid geen sprake van 'absolute' residualisering. Zoals veelvuldig in de literatuur wordt benadrukt, zorgt de Nederlandse traditie van het tegengaan van inkomenssegregatie door interventies in de woningmarkt ervoor dat ruimtelijke segregatie in Amsterdam, vergeleken met andere wereldsteden, relatief beperkt blijft (onder andere Vermeij \& Kullberg, 2015). Eerder is er sprake van uiteenlopende gradaties van residuali- 
sering of juist gentrificatie, en van toenemende contrasten die dicht naast elkaar bestaan binnen gebieden. ${ }^{6}$ Het beeld is bovendien dynamisch: gebieden die voorheen een concentratieplek van sociale huur waren, kunnen in enkele jaren, als gevolg van stedelijke vernieuwing en de grote verdichtingsopgave in delen van de stad, gemengde of sterk gegentrificeerde gebieden worden (zie bijvoorbeeld de Amsterdamse Kolenkitbuurt). Dat betekent vooral dat stedelijk sociaal werk erop toegerust moet zijn om op een flexibele manier in te spelen op een gedifferentieerde en continu veranderende lokale context.

\section{Geuzenveld: een aandachtswijk in beweging}

We illustreren onze discussie zo veel mogelijk aan de hand van een casus, namelijk de wijk Geuzenveld in Amsterdam Nieuw-West. In deze wijk doen wij in 2019 onderzoek naar de toegankelijkheid van sociale basisvoorzieningen voor de diverse bewonersgroepen. ${ }^{7}$ Een vraag die hierbij centraal staat, is of de basisvoorzieningen zijn toegerust op het opvangen van nieuwe kwetsbare groepen die ten gevolge van vermaatschappelijking in de zorg of de huisvesting van statushouders onderdeel uitmaken van de wijk.

Geuzenveld, dat in beleidsdocumenten vaak in combinatie wordt beschouwd met het aangrenzende Slotermeer, is sinds lange tijd onderwerp van wijkgericht beleid vanwege structurele sociaaleconomische achterstanden. De wijk maakte onderdeel uit van het krachtwijkenbeleid van het ministerie van Volkshuisvesting, Ruimtelijke Ordening en Milieubeheer (VROM) en de daarop volgende nationale en Amsterdamse beleidsinitiatieven gericht op de verbetering van de leefbaarheid, veiligheid en sociaaleconomische situatie van bewoners in het gebied (Permentier, Kullberg \& Van Noije, 2013). Het is een wijk met een hoog percentage bewoners met een niet-westerse achtergrond (63 procent), hoge werkloosheid, laaggeletterdheid en hoge sociale problematiek in brede zin. In het gebied wonen meer statushouders dan gemiddeld (9,2 per 1000 inwoners tegen 6,1 in Amsterdam; Gemeente Amsterdam, 2017a, 2). Het gebied scoort relatief ongunstig op inkomensindicatoren. De geregistreerde werkloosheid ligt met 13,7 procent boven het Amsterdamse gemiddelde (11,9 procent), het aandeel minimahuishoudens is met 22 procent hoog (Gemeente Amsterdam, 2019, 15). Stadsdeel NieuwWest schrijft over het gebied: 'De bewoners [van dit gebied], in het bijzonder de jeugd van Geuzenveld-Slotermeer, hebben niet altijd dezelfde kansen om mee te doen' (Gemeente Amsterdam, 2019, 3). Sociale uitsluiting - de situatie waarin mensen vanwege omstandigheden niet volledig kunnen deelnemen aan de samenleving - ligt twee keer zo hoog als gemiddeld in de stad. Het corporatiebezit is hoger dan gemiddeld: 68 procent (versus 39 procent in Amsterdam (Gemeente Amsterdam, 2018a, 309). ${ }^{8}$ Tegelijkertijd is de gemiddelde huur lager dan elders in de stad. De wijk scoort relatief ongunstig op de beleving van leefbaarheid door bewoners (Gemeente Amsterdam \& Amsterdamse Federatie van Woningcorporaties, 2018).

De wijk wordt ook geraakt door actuele ontwikkelingen op de Amsterdamse woningmarkt. In dit deel van Nieuw-West staat een grootschalige stedelijke ver- 
nieuwingsopdracht in de planning, waarbij renovatie, sloop en nieuwbouw aan de orde (zullen) zijn. Geuzenveld zit al geruime tijd in de wachtkamer voor die vernieuwing, en in de tussentijd is er sprake van achterstallig onderhoud in de huidige sociale huurvoorraad. Veel bewoners zijn wantrouwend over de vernieuwingsplannen en vrezen verdringing. Een zekere 'participatiemoeheid' of tegenzin om (opnieuw) mee te praten over de grote toekomstige veranderingen in de wijk is dan ook kenmerkend (Majoor \& Welschen, 2018).

\section{Consequenties voor sociaal werk in Geuzenveld}

De cijfers lijken erop te wijzen dat Geuzenveld kan worden aangemerkt als een wijk waar residualisering plaatsvindt - een toenemende concentratie van sociale problematiek als gevolg van uitsorteringsprocessen op de woningmarkt. Wat zijn de uitdagingen voor sociaal werk in een wijk als Geuzenveld? Welke antwoorden worden gegeven op residualisering? We verkennen dit door na te gaan welke reacties we in het verleden en in het heden zien bij sociaal werk. Hierbij schenken we relatief veel aandacht aan Angelsaksische landen, waar residualisering al langer gaande is. Tegelijkertijd kijken we in hoeverre we ook al eerste weerspiegelingen zien in Nederlandse wijken waar sprake is van residualisering, zoals Geuzenveld.

De maatschappelijke kerntaak van sociaal professionals is het sociaal functioneren te bevorderen van 'mensen en hun sociale context' (Sectoraal Adviescollege Hogere Sociale Studies, 2017, 20). Sociaal werk heeft vele verschijningsvormen, zoals maatschappelijk werk dat zich richt op individuele begeleiding of op gezinnen (doorgaans aangeduid als 'casework'). Anderzijds is er ook community work, dat zich juist richt op groepen en gemeenschappen. ${ }^{9}$ Daarnaast wordt er vaak onderscheid gemaakt naar doelgroepen (jongeren, ouderen, migranten et cetera). De benamingen en werkzaamheden zijn divers en veranderen vaak (Hoijtink \& Spierts, 2017, 29-49). Tegenwoordig zien we vaak een samenballing van verschillende typen sociaal werkers in wijkteams. Een kenmerkende gemene deler is dat sociaal werkers zich sterk maken voor het zwakste belang; ze proberen diegenen in de meest kwetsbare posities een stem te geven (Spierts e.a., 2017). In het vervolg van dit artikel gaan we dieper in op de verschillende rollen voor het sociaal werk in reactie op de residualiseringsopgave.

\section{Echo's van eerdere antwoorden op residualisering: bewonersparticipatie bij sociale mix}

Zorgen over concentraties van kwetsbare bewoners zijn niet nieuw. De gekozen aanpakken kunnen evenwel in de tijd verschillen, en ook de rol van sociaal werkers kan dat. Bij de vorige fase van de wijkaanpak van gebieden met concentraties van lage inkomens was er een sterke aanname dat woningdifferentiatie een groot aantal van de (dreigende) 'buurteffecten' kon tackelen. Sociale mix gold als een wervend catch-all concept ${ }^{10}$ dat een antwoord moest bieden op uiteenlopende zaken als kansenongelijkheid, buurtstigma's, discriminatie op basis van woonplek, overladen professionals die schaarste moesten verdelen, een geïsoleerde 
bewonerscultuur, afwijkende socialisatie, geringe voorzieningen en lage leefbaarheid (Atkinson \& Kintrea, 2004).

Sociaal werkers waren in die periode vooral belangrijke partners van woningcorporaties bij het vaststellen van woonbehoeften en bij het betrekken van bewoners bij besprekingen over de nieuwe plannen voor de wijk. De facto bleek de op veel plaatsen doorgevoerde woningdifferentiatie in het kader van programma's voor stedelijke vernieuwing vooral een antwoord te zijn op de verminderde leefbaarheid en veiligheid van wijken (Wittebrood, Permentier \& Pinkster, 2011). In Engels onderzoek werd er sterk op gewezen dat verbeteringen en upgrading van de woningen en de woonomgevingen niet hand in hand gingen met de aanpak van armoedeproblemen (Kintrea, 2007). Arme gebieden die een toename van hoge inkomens lieten zien, zagen tegelijkertijd zelfs een toename van lage inkomens c.q. residualiseerden dus verder ondanks de fysieke vernieuwing (Rae e.a., 2016). Ook het community work van sociaal werkers maakte bij de planvorming niet altijd het verschil. Intensieve processen voor community development bij de zogenaamde New Deal for Communities (NDC) - dat wil zeggen cocreatieve processen waarbij bewoners meepraten over vernieuwingen in de wijk - leidden in Engeland niet tot meer bewonersengagement afgezet tegen wijken waar geen NDC-programma was (Lawless \& Pearson, 2012).

Bijna tien jaar later zien we een hernieuwde aandacht voor grootschalige woningprogramma's gericht op een sociale mix, maar niet meer als oplossing voor alle vraagstukken; het is nu vooral een specifiek instrument voor leefbaarheid. De mengingsgedachte richt zich nu deels ook op het realiseren van een 'magic mix' binnen sociale huurcomplexen. Het gaat om kleinschalige vormen van samenwonen van arme maar sociaal vaardige huurders, zoals studenten en arme, minder kansrijke huurders zoals statushouders of mensen afkomstig uit de maatschappelijke opvang. Door onderling contact en door principes van wederkerigheid moet er een proces van rolmodel-leren op gang komen (Costarelli, Kleinhans \& Mugnano, 2019).

Voor sociaal werkers betekent dit een heropleving van de rol als procesbegeleider en stimulator van bewonersparticipatie bij woondifferentiatie. De aandacht voor cocreatie is ondertussen onverminderd groot gebleven. Living labs en fieldlabs die ervoor moeten zorgen dat beleidsplannen beter aansluiten bij de geleefde wereld van bewoners zijn in Nederlandse steden vooral te vinden in gebieden met veel probleemwijken (Majoor e.a., 2017, 16-17). Sociaal werkers die zich richten op community work zijn ook nu weer veelvuldig betrokken bij dergelijke participatieprocessen. Concreet betekent het in Geuzenveld bijvoorbeeld dat het sociaal werk meedenkt om de participatiemoeheid bij wijkvernieuwingen en frustraties onder bewoners over de 'onzekere' toekomst van de wijk te overwinnen. Naast dit oppakken van deze bekende rol als procesbegeleider zien we ook nieuwe rollen en aandachtspunten voor sociaal werkers. Die schetsen we in de volgende paragrafen. 


\section{Werken met een zwaardere doelgroep}

Sociaal werkers die zich vooral richten op maatschappelijk werk en casework, dat wil zeggen het individueel begeleiden van personen, krijgen in wijken met residualisering te maken met steeds zwaardere doelgroepen. De populatie verarmt immers en alleen de doelgroepen met de allerzwaarste problematiek mogen worden toegelaten tot voorzieningen. Deels betreft het personen afkomstig uit de geestelijke gezondheidszorg (ggz) en de maatschappelijke opvang die veel begeleiding nodig hebben bij het zelfstandig wonen in de wijk. Maar het betreft ook mensen in allerlei andere (combinaties van) kwetsbare situaties, zoals langdurige werkloosheid, schuldenproblematiek, laaggeletterdheid, uitzichtloosheid, relatieproblemen, middelengebruik, eenzaamheid, huiselijk geweld of prostitutie.

Een groot deel van de doelgroep van sociale wijkteams (waarin verschillende sociale en zorgprofessionals samenwerken) in deze gebieden kan worden omschreven als sociaal uitgesloten. Veel van deze mensen verkeren in een toestand van materiële deprivatie, hun toegang tot zorg, huisvesting en onderwijs is gering en hun economische en sociale participatie is laag (Jehoel-Gijsbers, 2004). In het onderzoek Van Bergen e.a. (2014) wordt deze groep als volgt geschetst: 'Hun sociale netwerk is vaak beperkt en kwetsbaar. Ze kampen met veel gezondheidsproblemen, ervaren weinig regie over het eigen leven en hebben vaak een negatief of onrealistisch toekomstbeeld. Een laag inkomen en schulden veroorzaken bij deze groep veel stress.'

Een groot deel van deze groep heeft een niet-westerse achtergrond. Sociaal werkers weten hen niet altijd goed te bereiken. Onderzoek wijst bijvoorbeeld al jaren op ondergebruik van eerstelijnszorg- en welzijnsvoorzieningen door migrantengroepen. Onderzoek in Rotterdam van De Gruijter e.a. (2007) toonde aan dat voor eerste generatie migrantenvrouwen sprake was van een culturele afstand tot het formele zorg- en welzijnsaanbod: de 'cultuur van de instellingen' vormde voor ruim de helft van de ondervraagde vrouwen een struikelblok.

Een andere reden is dat de poortwachtersfunctie van sociaal werkers ook kan afschrikken. Veel mensen die moeite hebben met rondkomen onderhouden bijvoorbeeld ook problematische relaties met hulpverlenersinstanties (vergelijk Doorn e.a., 2013). Sociaal werkers staan relatief weinig stil bij dit onderbereik, omdat hun tijd en middelen schaars zijn en ze te maken hebben met grote caseloads. Veel tijd gaat ook zitten in het verwerken van soms heftige ervaringen. Engels onderzoek laat zien dat de zware emotionele belasting en de grote caseload leiden tot een groot verloop onder sociaal werkers in aandachtswijken (Clayton, Donovan \& Merchant, 2015).

We weten uit recente gesprekken met stakeholders in Geuzenveld en Slotermeer dat veel van de huidige bewoners in de sociale huurwoningen in dit gebied bijna permanent bezig zijn met overleven. Het moeilijk rondkomen speelt niet alleen bij mensen zonder werk, maar in toenemende mate ook bij de zogenaamde werkende armen. Het maken van financieel juiste beslissingen brengt in deze situatie 
veel stress met zich mee. Vaak wordt deze spanning nog eens vergroot doordat mensen het nodige wantrouwen ervaren vanuit overheid en schuldeisers. Een extra bron van stress is soms de aanwezigheid van buren met hun eigen individuele (schulden)problemen. Mensen met verschillende problematiek en soms met 'verward gedrag' komen boven of naast elkaar te wonen, wat spanningen oplevert.

\section{Welzijn als functie voor zorg}

Kenmerkend voor de doelgroep van sociaal werk in deze gebieden is dus een hoge mate van stress en vaak een grote zorgbehoefte vanuit de persoon zelf of vanuit diens omgeving. Om verwijzingen naar dure zorg te beteugelen worden welzijnsactiviteiten gericht op sociale participatie steeds vaker als middel ingezet om bijvoorbeeld mensen met psychische problematiek te bereiken en hun kwaliteit van leven te verbeteren. Binnen het liberale residualiseringsmodel geldt welzijn dus als een kostenbesparende werkwijze om dure zorgvragen te voorkomen of 'af te schalen'. Het gaat met andere woorden om een verschuiving van 'medicalisering' naar 'socialisering'.

In toenemende mate verwijzen huisartsen in achterstandsgebieden in Nederland en Engeland tegenwoordig bij stressgerelateerde klachten bijvoorbeeld naar het zogenaamde 'Welzijn op recept'. ${ }^{11}$ Zij verwijzen niet door naar dure medische zorg, maar naar community workers, gemeenschapscentra of verenigingen of naar vrijwilligersorganisaties die zich richten op creatieve activiteiten, kunst, lezen, onderwijs, gezond eten, beweging, doorverwijzing et cetera. De eerste effectmetingen in het Verenigd Koninkrijk laten positieve resultaten zien in termen van afnemende spanning en minder negatieve gestemdheid bij patiënten (Chatterjee e.a., 2018). Soms vormt gezondheid zelfs de hoofdmoot van antistressprogramma's in arme Engelse wijken; zie bijvoorbeeld 'Well London' (Phillips e.a., 2014) of 'Go Well' in Glasgow. In Nederland valt - op veel kleinere schaal - bijvoorbeeld te denken aan het programma 'Samen Beter' (www.samenbeter.org).

In Geuzenveld zien we in onze verkenningen discussie over de vraag in hoeverre community workers en 'sociale basisvoorzieningen' zoals bibliotheken, Huizen van de Wijk en sportclubs een taak hebben in het bieden van lichte vormen van ondersteuning en dagbesteding aan moeilijk bereikbare bewoners met stressgerelateerde problemen. Er zijn zorgen dat investeren in bewonersondersteuning en bewonersactiviteiten niet langer te boek staat als een intrinsiek goed voor een relatief grote groep arme buurtbewoners die bijvoorbeeld steun bij elkaar zoeken, maar specifiek gaat gelden als een 'preventie-instrument' voor het betaalbaar houden van zorgvoorzieningen voor bijzondere doelgroepen. Sociaal werkers voorzien dat de relationele aspecten van community building, zoals ervoor zorgen dat zowel zittende als nieuwe bewoners zich thuis voelen in veranderende wijken, minder ruimte krijgen. Ofwel dat het werken aan groepsbinding binnen relatief beschermde omgevingen (zoals bijvoorbeeld buurtcirkels voor kwetsbare groepen bewoners) en het werken aan overbruggende contacten in meer gemengde omge- 
vingen hoofdzakelijk in het teken komen te staan van bijdragen aan de-medicalisering.

\section{Samenwerken met bewoners en sociale ondernemingen als coleveranciers van dienstverlening}

Een derde ontwikkeling die we zien in wijken waar residualisering plaatsvindt is dat ook hier een groot beroep wordt gedaan op de gemeenschap en de markt als coleveranciers van welzijn. Dit past in de gedachte van bijvoorbeeld de Wet maatschappelijke ondersteuning dat niet alleen de overheid, maar meerdere sectoren de verantwoordelijkheid dragen voor de meest behoeftigen in de samenleving. Het probleem is vaak echter dat de samenwerking tussen wijkteams en partijen uit de civil society in deze wijken relatief moeizaam verloopt. Het punt is niet zozeer dat er nauwelijks of geen initiatieven van bewoners, vrijwilligers of sociale ondernemers zijn in deze gebieden, zoals soms wel wordt aangenomen. Wel zijn deze initiatieven vaak onderling sterk gefragmenteerd. Ze zijn enerzijds sterk gericht op de eigen groep en ze onderhouden anderzijds vaak moeizame relaties met community workers.

Grootschalig Amerikaans onderzoek laat zien dat in buurten waar de gemiddelde sociaaleconomische status laag is, er vaak ook minder sociale organisatie is dan elders, terwijl er juist meer problemen zijn die om oplossingen vragen (Kingston, Huizinga \& Elliott, 2009). Dat is niet zo verrassend: bewoners met individuele sociale problemen hebben vaak hun handen vol aan het op de rails houden van hun eigen leven. Ruimte voor een actieve inzet op collectieve thema's in de buurt is dan niet vanzelfsprekend. De lage beleving van de leefbaarheid en de sociale cohesie in de buurt zorgen ervoor dat bewoners minder geneigd zijn om samen met andere bewoners kwesties op te pakken.

Kwalitatief onderzoek in Nederlandse armere wijken geeft echter een meer gelaagd beeld van de sociale samenhang dan sommige kwantitatieve studies en aannames in het beleid over 'terugtrekgedrag' in arme diverse stadswijken doen vermoeden. De Gruijter e.a. (2007) observeerden in onderzoek in Rotterdam wel degelijk veel zelforganiserend vermogen en sterke informele netwerken onder de migrantenvrouwen. Pinkster beschreef hoe in de achterstandswijk Transvaal (Den Haag) weliswaar sprake was van geringe sociale cohesie op buurtniveau, maar dat er tegelijk hele sterke informele ondersteuningsnetwerken waren binnen de verschillende etnische bewonersgroepen (Pinkster, 2007). Indicatoren van achterstand, zo stelde Blokland, dekken niet de mate waarin binnen een buurt sociale netwerken bestaan die betekenis hebben voor mensen $(2001,51)$. Recenter onderzoek bevestigt het beeld dat er in armere wijken wel degelijk sprake is van zelforganisatie, zij het vaak etnisch gefragmenteerd (Bosch, 2016).

Onderzoek uit Vlaanderen gaat dieper in op de sociale structuren in zogenaamde migrantenwijken die op allerlei manieren aan informeel sociaal werk doen. Dit onderzoek wijst erop dat zelfredzaamheid en eigen kracht en de idealen van de 
participatiesamenleving in deze wijken en gemeenschappen wel degelijk onderdeel vormen van de dagelijkse praktijk. De informele 'sociaalwerkpraktijken', zoals de Vlaamse auteurs dit noemen, zijn nog onvoldoende bekend bij formele sociaal werkers. Volgens de auteurs ontstaan deze praktijken 'uit concrete overlevingsnoden van kwetsbare bewoners en groepen, die door de (terugtredende) welvaartstaat onvoldoende geadresseerd worden' (Schrooten, Thys \& Debruyne, 2019).

Wij zagen ditzelfde beeld in eerder onderzoek in Amsterdam: migrantenzelforganisaties springen in het vacuüm dat ontstaat door het gebrek aan aansluiting van het formele sociaal werk bij bepaalde stedelijke migrantengroepen (Welschen, 2019). In de eerste verkenning voor ons onderzoek in Geuzenveld worden deze beelden bevestigd. Het speelveld van maatschappelijke ondersteuning in een wijk als Geuzenveld is een fijnmazig geheel, met allerlei verschillende actoren die lang niet allemaal goed in beeld zijn bij het beleid of bij formeel sociaal werk en soms dus in de schaduw blijven. Samenwerking tussen formele en informele partijen als coleveranciers van welzijn aan bewoners verloopt daardoor moeizaam.

Een bijzondere en vaak wel duidelijk zichtbare variant van informele ondersteuning zijn sociale ondernemingen. In navolging van Angelsaksische steden met een beperkt aanbod van door de overheid gefinancierde sociale voorzieningen zien we ook in de stadswijken van Nederlandse 'verzorgingssteden' voorzichtige en nog zeer kleinschalige niet-commerciële sociale ondernemingen opkomen die zich als nieuwe aanbieders manifesteren. In de Verenigde Staten zijn community-based enterprises inmiddels de meest voorkomende vorm van community-organisaties en in sommige gebieden de belangrijkste leveranciers van sociale voorzieningen zoals rechtshulp, arbeidstraining of zelfs sociale huisvesting. Ze blijken tot dusver echter niet erg succesvol in de meest gedepriveerde gebieden, zoals Van Ham en anderen aantonen, omdat het voor deze gebieden moeilijk is om externe financiering aan te trekken (Van Ham e.a., 2017). Uit dezelfde literatuur blijkt dat in Nederland sociale professionals nieuw gevormde sociale ondernemingen vaak intensief ondersteunen. Tegelijkertijd hebben de professionals - zeker ook in gebieden met veel residualisering - veel twijfels of sociale initiatieven de voor kwetsbare groepen noodzakelijke voorzieningen wel duurzaam kunnen bieden.

Eerder concludeerden wij dat er in het fijnmazige speelveld van formele en informele aanbieders van sociale voorzieningen in stadswijken veel wij-zij-denken, wederzijdse onbekendheid en wantrouwen bestaan (Veldboer \& Hoijtink, 2019). Ook in Geuzenveld lijkt op basis van onze gesprekken dit beeld van een kloof te worden bevestigd. Mogelijk gaat het zelfs om een kloof op meerdere niveaus: tussen bepaalde bewonersgroepen en formele voorzieningen, tussen formele en informele 'sociaalwerkpraktijken', maar ook tussen de verschillende zelforganisaties die vaak (etnisch) gefragmenteerd zijn. Er is dus in Geuzenveld wel een veelheid van partijen actief, maar zij slagen er moeilijk in om een gezamenlijke vuist te maken tegenover problemen in deze gebieden, zoals verloedering. 


\section{De kloof overbruggen: link work}

We kunnen constateren dat het leggen van verbindingen tussen moeilijk bereikbare of wantrouwende bewoners enerzijds en formele organisaties anderzijds, of tussen formele organisaties en zelforganisaties, een van de voornaamste uitdagingen is voor sociaal werk in wijken waar sprake is van residualisering. Deze vorm van verbinden heet in de literatuur link work (Fretwell e.a., 2018). ${ }^{12}$

Linking sociaal kapitaal verwijst slechts beperkt naar de horizontale verbindingen binnen en tussen sociale groepen, zoals de bekendere begrippen bonding en bridging sociaal kapitaal doen. Linking sociaal kapitaal verwijst primair naar 'verticale' verbindingen tussen groepen in de samenleving en overheidspartijen (Hawkins \& Maurer, 2009). De gedachte in de literatuur is dat die verticale relaties tussen burgers enerzijds en professionals of de overheid anderzijds in het bijzonder van belang zijn voor sociaal geïsoleerde groepen, omdat ze hen in contact brengen met hulpbronnen zoals onderwijs, arbeidsmarkt en gezondheidszorg (zie bijvoorbeeld Horjus \& Van Dijken, 2017). Linkworkers zijn personen die beschikken over de vaardigheden om die verticale verbindingen te leggen: ze spreken de taal van en hebben een netwerk in zowel de wereld van geïsoleerde bewoners als die van instellingen.

In een context van laag vertrouwen en moeilijk bereikbare doelgroepen is link work voor professionals ogenschijnlijk essentieel, of zij nu casework of community work verrichten. De sociaal werker van nu kan in het ideale geval niet alleen soepel schakelen tussen casework op kantoor en outreachend werken in de wijk, maar moet ook bekwaam zijn in link work.

Link work in residualiseringswijken kan de vertrouwenskloof slechten door gebruik te maken van vormen van democratisch professionalisme. Dit houdt in dat met cliënten en met andere professionals voortdurend in dialoog wordt gehandeld (Spierts, 2017b). Een voorbeeld van professionele linkworkers zijn de zogenaamde 'best persons' die door Van den Brink (Van den Brink e.a., 2012) zijn beschreven. Best persons winnen het vertrouwen van moeilijk te bereiken bewoners doordat ze een langdurige inzet en betrokkenheid bij die bewoners tonen. Tegelijk zijn zij voortdurend aan het verbinden. Van der Pennen (2012) schrijft hierover: 'best persons (...) leggen verbindingen tussen de systeem- en leefwereld door vanuit de formele organisatie actief contact te zoeken met wijkbewoners. Ze zijn vaak meertalig, letterlijk, maar ook in de zin dat ze de taal van het stadhuis en de taal van de straat beheersen. ${ }^{13}$ In eerder onderzoek kwamen wij dit type professional in Amsterdamse stadswijken al tegen, bijvoorbeeld in de persoon van een klantmanager activering die elke week aan de koffietafel in het Huis van de Wijk kantoor houdt en daardoor veel makkelijker vindbaar en benaderbaar is voor bewoners in kwetsbare posities(Welschen e.a., 2018).

Vergelijkbare kwaliteiten zien we terug bij personen die actief zijn bij informele partijen in residualiseringswijken. In de voorgaande paragraaf beschreven we de centrale rol van zelforganisaties, soms langs etnische lijnen georganiseerd. Eerder onderzoek door ons in Slotervaart liet bijvoorbeeld zien dat migrantenzelforganisaties een bemiddelende rol innemen tussen gezinnen, huisartsen, politie en jeugdzorg. ${ }^{14}$ In Oud-Noord zagen we dat deze brugfunctie van informele partijen 
zich niet beperkt tot migrantengemeenschappen (Welschen e.a., 2018). Ook bij autochtone bewoners, die door gebrek aan vertrouwen afstand ervaren tot het formele aanbod, neemt de informele partij een cruciale rol in als schakel naar het professionele aanbod. Wat hun positie daarbij versterkt, is dat ze zich onderscheiden van formele organisaties en professionals. Informele partijen benadrukken sterk het verschil tussen hun eigen aanpak en die van formele werkers. Ze brengen veel tijd met bewoners door, houden zich niet aan kantooruren en hebben 'hun voordeur altijd openstaan'. Bewoners associëren informele partijen niet met hulpverlening en nemen hen dan ook sneller in vertrouwen. Hun rol als gids vullen de informele partijen op uiteenlopende manieren in: van het meenemen van folders over het ondersteuningsaanbod in de buurt tot het begeleiden van bewoners naar gesprekken met instanties en daar, indien nodig, het woord overnemen. Soms is de ondersteuning meer indirect door te luisteren of voor iemand te bidden. Dat kan net het zetje zijn dat een bewoner nodig heeft om zijn of haar problemen aan te pakken en hulp te vragen bij formele organisaties.

\section{Conclusie}

Sociaal werk vindt vaak plaats in een stedelijk decor en wordt door veranderingen in dat decor ook sterk beïnvloed. De meest kenmerkende ontwikkeling in de stad Amsterdam is de toenemende segmentering op de woningmarkt. In de centrumgebieden zijn hogere inkomens - de winnaars van de economische groei - steeds dominanter in de meest gewilde buurten. In gebieden aan de rand van de stad met veel sociale huurwoningen neemt daarentegen de armoedeproblematiek toe. Dit is het gevolg van een residuaal welvaarts- en woningmodel waarbij goedkope woningen in de Amsterdamse sociale huursector passend c.q. strikt worden toegewezen aan mensen met weinig bestaanszekerheid en aan bijzondere doelgroepen met veel ondersteuningsvragen, zoals bijvoorbeeld woningzoekenden met een achtergrond in de ggz.

We verwachten in wijken aan de rand van de stad, zoals Geuzenveld, de komende jaren een grote 'residualiseringsopgave' aan te treffen voor het sociaal werk. De opeenstapeling van sociale problematiek en ook van etnische concentraties in huurcomplexen zal verder toenemen, zelfs als er in de toekomst fysieke ingrepen plaatsvinden. Deze ontwikkeling van een steeds omvangrijkere workload door veranderingen op de woningmarkt kan niet los worden gezien van gelijktijdige en samenhangende opgaven zoals vermaatschappelijking en de decentralisering van het sociaal werk.

Zoals we in dit artikel hebben geschetst aan de hand van binnenlandse en buitenlandse literatuur, valt de residualiseringsopgave voor sociaal werk in verschillende onderdelen uiteen. Die onderdelen vragen elk om verschillende rollen of aandachtsgebieden voor sociaal werkers in deze stadswijken.

Een bekend antwoord op residualisering is het stimuleren van een sociale mix door stedelijke vernieuwing. Bij dat soort processen wordt de community werker van oudsher ingezet om bewonersparticipatie vorm te geven. Tegelijk is bekend dat het bevorderen van een sociale inkomensmix maar zeer beperkt leidt tot een 
keerpunt in de opeenstapeling van sociale problematiek onder bewoners in de sociale huursector. Met andere woorden, de residualisering in de sociale huursector zet door.

Er zijn dus andere antwoorden en rollen van sociaal werkers nodig om in deze gebieden kwetsbare bewoners te ondersteunen en op te komen voor het zwakste belang. We schetsten de noodzaak om te leren werken met een steeds zwaardere doelgroep, een groep die soms zorgmijdend is en door andere bewoners als onveilig wordt ervaren. Een cruciale uitdaging daarbij is de afstand die sommige groepen ervaren tot de formele hulpverlening. Professionals lopen tegen die kloof aan, maar hebben door hun zware caseload onvoldoende tijd en ruimte om stil te staan bij manieren of werkwijzen om die kloof daadwerkelijk te overbruggen.

Tegelijkertijd zijn de verwachtingen over het welzijnswerk hoog, juist ook in gebieden met residualisering. Welzijnswerk wordt steeds vaker ingezet om uiteenlopende groepen beschermde ontmoetingsplekken aan te bieden in de wijk, maar ook als alternatief voor zwaardere, duurdere zorg; zie het voorbeeld van 'Welzijn op Recept'. Daarmee verschuift het accent in de zorgverlening van het domein van medicalisering naar het domein van socialisering. Hierdoor gaan welzijnspartijen en sociaal werkers ook een grotere verantwoordelijkheid dragen voor het bereik en de effectiviteit van zorgvoorzieningen. Daar komt nog een fundamentelere verschuiving bij, die onderdeel is van de decentralisering van het sociaal werk: het faciliteren van een transitie van een verzorgingsstaat naar een participatiesamenleving. Welzijn is binnen die verschuiving niet langer uitsluitend het domein van de overheid en publieke instituties, maar wordt in toenemende mate gecoproduceerd door partijen buiten de overheid - niet in de laatste plaats de gemeenschap of 'civil society' zelf. Juist in deze gebieden blijkt dit vaak een complexe opgave, omdat de inzet van bewoners sterk gefragmenteerd is.

Sociaal werkers van nu bevinden zich daarmee in een veel complexer speelveld dan voorheen, waarbij ze zich moeten verhouden tot een breed en fijnmazig pallet aan allerhande spelers en coleveranciers van welzijn.

Tegen de achtergrond van deze verschillende uitdagingen is link work volgens ons een cruciaal onderdeel van sociaal werk in stadswijken waar sociale problematiek zich opstapelt. Een steeds terugkerend thema bij alle geschetste uitdagingen is het belang van overbruggen, van verbinden. Om doelgroepen met zware en stille problematiek te bereiken. Om beter samen te werken met informele aanbieders van welzijn die in de schaduw opereren. Of juist met zorginstellingen die onvoldoende zicht hebben op de 'sociale kaart' en terugvallen op de bekende, maar misschien niet meest effectieve, opties. Om te zoeken naar manieren waardoor participatie in stedelijke vernieuwingstrajecten ook voor bewoners in de overlevingsstand van waarde is. De sociaal werker van nu moet in de eerste plaats een fijngevoelige antenne ontwikkelen om in al die verschillende werelden te kunnen opereren en deze met elkaar te verbinden.

Juist in die wijken en onder die bewoners voor wie eigen kracht en zelfredzaamheid niet vanzelfsprekend zijn, zijn sociaal werkers en informele partijen met linking sociaal kapitaal daarom naar onze verwachting van onmisbare waarde. Ze zijn de smeerolie die ervoor zorgt dat bewoners op die plekken niet verder op achterstand komen te staan. 
Ons lopende onderzoek in Geuzenveld vormt een eerste stap om de bestaande literatuur over residualisering verder toe te spitsen op het sociaal werk in Amsterdam en om onze verwachtingen over het belang van link work aan de empirie te toetsen. Dit onderzoek is een verkennende lokale casestudie, die vanuit een microsociologisch perspectief inzicht moet geven in de praktijken van sociaal werk in de huidige stedelijke context. Dat biedt handvatten voor professionals die in soortgelijke wijken werken, en voor studenten die zich voorbereiden op een loopbaan als sociaal werker in de stad.

\section{Noten}

1 In de geschiedenis van sociaal werk is de focus op stadsbewoners op achterstand een constante. Vanuit welke lens wordt gekeken, kan sterk verschillen. Dit hangt vaak samen met beleidstrends. Na de Tweede Wereldoorlog werd bijvoorbeeld gesproken over onmaatschappelijkheidsbestrijding als opdracht van stedelijk sociaal werk. In de hoogtijdagen van de verzorgingsstaat ging het echter over het tegengaan van sociale onrechtvaardigheid en sociale uitsluiting. Tegenwoordig willen nationale en lokale beleidsmakers graag dat stedelijke groepen op achterstand en dan met name migrantengroepen op eigen kracht hun weg kunnen vinden in de Nederlandse samenleving. Professionals moeten samen met de betrokkenen zelf en in 'samenspel' met mantelzorgers, vrijwilligers en bewonersgroepen deze eigen kracht ondersteunen. Niet de overheid, maar de gemeenschap of de markt (buurteconomie) wordt als belangrijkste 'geluksmachine' aangemerkt.

2 Volgens Florida gaat de new urban crisis vooral over een toenemende ongelijkheid in steden, onbetaalbare huisvesting, een wegtrekkende middenklasse, concentratie van hogere inkomensgroepen in centrale delen van de stad en een verdringing naar de periferie van lagere inkomensgroepen (Florida, 2017).

3 Residualisering draagt als term het risico van stigmatisering van buurten met zich, doordat sociale huur door het proces van residualisering steeds sterker geassocieerd wordt met achterstand (zie bijvoorbeeld Atkinson \& Jacobs, 2008). Tegelijkertijd is het van belang om de consequenties van ontwikkelingen op de woningmarkt voor sociale problematiek in buurten helder te benoemen; alleen op die manier kunnen sociaal werkers in stadswijken goed worden voorbereid op hun rol.

4 Dit beeld komt naar voren uit gesprekken met corporatiemedewerkers die door ons zijn geïnterviewd.

5 Sociaal werkers vervullen in dit model de rol van poortwachters die strikt de regels (moeten) interpreteren. Een voorbeeld is de constatering van de G4-rekenkamers dat in de nasleep van de economische crisis door schaarste van opvang en woningen alleen de allerzwaarste gevallen van dakloze verslaafden en dakloze psychiatrische patiënten in de Nederlandse grote steden door street level bureaucrats zijn geholpen en doorverwezen naar opvang- en woontrajecten. Zie: De Ridder, Kok \& Van Doorn, 2018.

6 Zie bijvoorbeeld de beschrijving van ontwikkelingen in Oud-Noord door Van de Kamp en Welschen, elders in dit tijdschrift. 
7 Dit onderzoek wordt uitgevoerd door het lectoraat Stedelijk Sociaal Werken van de Hogeschool van Amsterdam, in de context van de Werkplaats Sociaal Domein Amsterdam en Omgeving.

8 In 2017 was het aandeel sociale huurwoningen in het corporatiebezit voor de gehele stad Amsterdam 39 procent; zie Gemeente Amsterdam, 2018a, 309.

9 Casework richt zich op hulp- en dienstverlening aan individuen en gezinnen. Community work verwijst naar groepswerk of 'social group work', dat zich door middel van samenlevingsopbouw richt op het versterken van gemeenschappen. Zie onder andere Spierts e.a., 2017.

10 Sociale mix past in veel verzorgingsstaatmodellen (sociaaldemocratisch, liberaal, communitaristisch). Het is deels ook sterk verwant aan ideeën over een sociale investeringsstaat waarin vanuit publieke partijen voorwaarden worden gecreëerd voor 'meedoen'.

11 'Welzijn op recept' heeft betrekking op een aanpak waarbij zorgverleners zoals huisartsen een recept uitschrijven voor welzijn en via welzijnscoaches patiënten doorverwijzen naar voor hen aantrekkelijke welzijnsactiviteiten. Het is dus gericht op een intensieve samenwerking tussen eerstelijnszorg en welzijn (Sinnema e.a., 2014).

12 Zowel bij 'Welzijn op recept' als bij 'Veerkracht' zien we ook een belangrijk accent op link work door community workers, zie Mercer e.a., 2017.

13 Koster (2014) vraagt zich in een kritische bespreking van het 'best persons'-concept overigens af of zaken als empathie en betrokkenheid bij bewoners niet slechts bepaalde technieken zijn en dat professionele 'best persons' vooral overheidsdoelen dienen.

14 Hogeschool van Amsterdam, Wijkteamonderzoek Slotervaart (te verschijnen), zie ook Ponzoni \& Distelbrink, 2015.

\section{Literatuur}

Andersson, R., \& Turner, L.M. (2014). Segregation, gentrification, and residualisation: from public housing to market-driven housing allocation in inner city Stockholm. International Journal of Housing Policy, 14 (1), 3-29.

Atkinson, R.G., \& Jacobs, K. (2008). Public housing in Australia: Stigma, home and opportunity.

Atkinson, R., \& Kintrea, K. (2004). 'Opportunities and Despair, it's all in there' Practitioner Experiences and Explanations of Area Effects and Life Chances. Sociology, 38 (3): 437-455.

Bergen, A. van, Loon, A. van, Ballering, C., Carlier, B., \& Aangeenbrug, M. (2014). Sociaal uitgesloten in de grote stad. Academische Werkplaats User-G4.

Blokland, T. (2001). Middenklassers als middel. Het grotestedenbeleid en de betekenis van midden-en hogere inkomensgroepen voor grootstedelijk sociaal kapitaal. Beleid en Maatschappij, 28 (1): 42-53.

Bosch, E. (2016). The 'self organization' of welfare services in deprived and wealthier urban neighbourhoods in the Dutch Participation Society (PhD-thesis). 2016.

Boterman, W., \& Gent, W. van (2015). Segregatie in Amsterdam. Stedenbouw \& Ruimtelijke Ordening, 3: 34-39.

Brink, G.J.M. van den, Hulst, M.J. van, Graaf, L.J. de, \& Pennen, T. van der (2012). Best persons en hun betekenis voor de Nederlandse achterstandswijk. 
Chatterjee, H.J., Camic, P.M., Lockyer, B., \& Thomson, L.J. (2018). Non-clinical community interventions: a systematised review of social prescribing schemes. Arts \& Health, 10 (2): 97-123.

Clayton, J., Donovan, C., \& Merchant, J. (2015). Emotions of austerity: Care and commitment in public service delivery in the North East of England. Emotion, Space and Society, 14: 24-32.

Costarelli, I., Kleinhans, R., \& Mugnano, S. (2019). Reframing social mix in affordable housing initiatives in Italy and in the Netherlands. Closing the gap between discourses and practices? Cities, 90: 131-140.

Doorn, C., Huber, M.A., Kemmeren, C., Linde, J.M., Räkers, M., \& Uden, T. van (red.) (2013). Outreachend werkt! . Movisie, kennis en aanpak van maatschappelijke ontwikkeling.

Engbersen, G., \& Engbersen, R. (2014). Van buurtbarbecue naar buurtinfrastructuur. Corporaties en het veranderend sociaal domein (essay). Amsterdam: Prezco.

Esping-Andersen, G. (1990). The three worlds of welfare capitalism. Londen: Polity.

Florida, R. (2017). The new urban crisis: gentrification, housing bubbles, growing inequality, and what we can do about it. Oneworld Publications.

Fretwell, N., Osgood, J., O’Toole, G., \& Tsouroufli, M. (2018). Governing through trust: Community based link workers and parental engagement in education. British Educational Research Journal, 44 (6): 1047-1063.

Gemeente Amsterdam (2015). Staat van de Stad Amsterdam VIII. www.ois.amsterdam.nl/ nieuwsarchief/2015/de-staat-van-de-stad-ongelijkheid-in-de-stad, geraadpleegd op 5 juni 2019.

Gemeente Amsterdam (2017a). Gebiedsanalyse Slotermeer Geuzenveld Sloterdijken 2017. www.ois.amsterdam.nl/downloads/pdf/2017_gebiedsanalyse_6.pdf, geraadpleegd op 26 maart 2019.

Gemeente Amsterdam (2017b). Wonen in de Metropoolregio Amsterdam. www.amsterdam.nl/ois/projecten-data/wonen-metropoolregio/, geraadpleegd op 24 maart 2019.

Gemeente Amsterdam (2018a). Amsterdam in cijfers 2018. www.ois.amsterdam.nl/.../ 2018\%20jaarboek\%20amsterdam\%20in\%20cijfers.pdf, geraadpleegd op 5 juni 2019.

Gemeente Amsterdam (2018b). Factsheet Kerncijfers Armoede in Amsterdam. www.ois.amsterdam.nl/nieuws/kerncijfers-armoede-in-amsterdam, geraadpleegd op 26 maart 2019.

Gemeente Amsterdam (2019). Gebiedsplan Geuzenveld-Slotermeer, 2019. www.amsterdam.nl/bestuur-organisatie/stadsdelen/gebiedsgericht/ gebiedsplannen-2019/gebiedsplannen-nieuw/geuzenveld/, geraadpleegd op 26 maart 2019.

Gemeente Amsterdam \& Amsterdamse Federatie van Woningcorporaties (2018). Factsheet Wonen in Amsterdam, Leefbaarheid 2017.www.afwc.nl/uploads/tx_news/ Factsheet_leefbaarheid_Wonen_in_Amsterdam_2017.pdf, geraadpleegd op 5 juni 2019.

Gruijter, M. de, Boonstra, N., Pels, T., \& Distelbrink, M. (2007). Allochtone vrouwen doen mee! Eerste generatie allochtone vrouwen in Rotterdam en hun perspectief op activering. Utrecht: Verwey Jonker.

Ham, M. van, Reuschke, D., Kleinhans, R., Mason, C., \& Syrett, S. (red.) (2017). Entrepreneurial Neighbourhoods: Towards an Understanding of the Economies of Neighbourhoods and Communities (serie Entrepreneurship, space and place). Cheltenham: Edward Elgar. 
Hawkins, R.L., \& Maurer, K. (2009). Bonding, bridging and linking: how social capital operated in New Orleans following Hurricane Katrina. British Journal of Social Work, 40 (6): 1777-1793.

Hochstenbach, C., \& Musterd, S. (te verschijnen). The suburbanization, segregation and changing geography of different forms of poverty in Dutch metropolitan regions.

Hogeschool van Amsterdam (te verschijnen). Wijkteamonderzoek Slotervaart.

Hoijtink, M., \& Spierts, M. (2017). Sociale dimensies van 'sociaal' werk. De brede basis van het sociaal werk, 29-49.

Horjus, B., \& Dijken, M. van (2017). Op zoek naar verbinding in de samenleving. Pedagogiek, 37 (2): 119-130.

Jacobs, K., Atkinson, R.G., Spinney, A., Colic Peisker, V., Berry, M., \& Dalton, T. (2010). What future for public housing? A critical analysis. Australian Housing and Urban Research Institute.

Jehoel-Gijsbers, G. (2004). Sociale uitsluiting; een conceptuele en empirische verkenning. SCP.

Jonkman, A., Janssen-Jansen, L., \& Schilder, F. (2018). Rent increase strategies and distributive justice: the socio-spatial effects of rent control policy in Amsterdam. Journal of Housing and the Built Environment, 33 (4): 653-673.

Kingston, B., Huizinga, D., \& Elliott, D.S. (2009). A test of social disorganization theory in high-risk urban neighborhoods. Youth \& Society, 41 (1): 53-79.

Kintrea, K. (2007). Policies and Programmes for Disadvantaged Neighbourhoods: Recent English Experience. Housing Studies, 22 (2): 261-282.

Koster, M. (2014). Bridging the cap in the Dutch participation society: New spaces of governance, brokers, and informal politics. Etnofoor, 26 (2): 49-64.

Lawless, P., \& Pearson, S. (2012). Outcomes from community engagement in urban regeneration: Evidence from England's New Deal for Communities Programme. Planning Theory \& Practice, 13 (4): 509-527.

Majoor, S., Morel, M., Straathof, A., Suurenbroek, F., \& Winden, W. van (2017). Laboratorium Amsterdam: werken, leren, reflecteren, 16-17.

Majoor, S., \& Welschen, S. (2018). Verkenning Burgermeester Röellstraat (ongepubliceerd document).

Mercer, S.W., Fitzpatrick, B., Grant, L., Chng, N.R., O’Donnell, C.A., Mackenzie, M., \& Wyke, S. (2017). The Glasgow 'Deep End' Links Worker Study Protocol: a quasi-experimental evaluation of a social prescribing intervention for patients with complex needs in areas of high socioeconomic deprivation. Journal of Comorbidity, 7 (1): 1-10.

Morris, A. (2015). The residualisation of public housing and its impact on older tenants in inner-city Sydney, Australia. Journal of sociology, 51 (2): 154-169.

Pennen, T. van der (2012). Best persons maken het verschil in probleemwijken. www.socialevraagstukken.nl/best-persons-maken-het-verschil-in-probleemwijken/, geraadpleegd op 31 mei 2019.

Permentier, M., Kullberg, J., \& Noije, L. van (2013). Werk aan de wijk. Den Haag: Sociaal Cultureel Planbureau.

Phillips, G., Bottomley, C., Schmidt, E., Tobi, P., Lais, S., Yu, G., \& Clow, A. (2014). Well London Phase 1: Results among adults of a cluster-randomised trial of a community engagement approach to improving health behaviours and mental wellbeing in deprived inner-city neighbourhoods. Journal of Epidemiology Community Health, 68: 606-614.

Pinkster, F.M. (2007). Localised social networks, socialisation and social mobility in a lowincome neighbourhood in the Netherlands. Urban Studies, 44 (13): 2587-2603.

Platform31. www.platform31.nl/publicaties/evaluatie-passend-toewijzen, geraadpleegd op 30 april 2019. 
Ponzoni, E., \& Distelbrink, M. (2015). Opvoedsteun in de buurt. Schakelen tussen formele en informele voorzieningen.

Rae, A., Hamilton, R., Crisp, R., \& Powell, R. (2016). Overcoming deprivation and disconnection in UK cities. York: Joseph Rowntree Foundation.

Ridder, J. de, Kok, A., \& Doorn, M. van (2018). Access to homelessness services and housing Amsterdam. Feantsa Homeless in Europe Magazine, voorjaar: 10-12.

RIGO (2018). Veerkracht in het corporatiebezit: Kwetsbare bewoners en leefbaarheid (eindrapport).

Samen Beter: Bouwt aan Vitale Wijken. www.samenbeter.org/, geraadpleegd op 5 juni 2019.

Schout, G. (2012). Competenties van professionals. In: Wat elke professional over de oggz moet weten. Houten: Bohn Stafleu van Loghum, 47-51.

Schrooten, M., Thys, R., \& Debruyne, P. (2019). Sociaal Schaduwwerk: over informele spelers in het welzijnslandschap. Politeia.

Sectoraal Adviescollege Hogere Sociale Studies (2017). Landelijk Opleidingsdocument sociaal werk.www.vereniginghogescholen.nl/system/profiles/documents/000/000/212/ original/Landelijk_opleidingsdocument_Sociaal_Werk_-_downloadversie.pdf? 1494439200, geraadpleegd op 5 juni 2019.

Sinnema, H., Smiesing, J., Ruiter, M. de, Vossepoel, L., Bolier, L., Muntingh, A., \& Groot, K. de (2014). Welzijn op recept. Handleiding voor de ontwikkeling en invoering van het welzijnsrecept. Utrecht: Trimbos.

Spierts, M. (2017a). Democratische professionals. Vakblad Sociaal Werk, 18 (3): 31-33.

Spierts, M. (2017b). Pleidooi voor een democratisch sociaal werk.

Spierts, M., Sprinkhuizen, A., Scholte, M., Hoijtink, M., Jonge, E. de, \& Doorn, L. van (2017). De brede basis van het sociaal werk: grondslagen, methoden en praktijken.

Veldboer, L. (2018). De stad als setting van sociaal werk (lectorale rede). Hogeschool van Amsterdam.

Veldboer, L., \& Hoijtink, M. (2019). Hybridisering van wijkteams en vrijwilligersinitiatieven lijkt nog ver weg. Sociale Vraagstukken, 17 april.

Vermeij, L., \& Kullberg, J. (2015). Niet van de Straat. Sociaal Cultureel Planbureau.

Welschen, S. (2019). Informele partijen zijn hulpverleningsgids voor wantrouwende Amsterdammers. Sociale Vraagstukken, 24 april.

Welschen, S., Metze, R., Haijen, J., \& Rijnders, J. (2018). Met elkaar of naast elkaar? Wijkteamprofessionals en informele krachten in Oud Noord over kwesties bij de gezamenlijke ondersteuning aan huishoudens in kwetsbare posities.

Wittebrood, K., Permentier, M., \& Pinkster, F. (2011). Wonen, wijken \& interventies: krachtwijkenbeleid in perspectief. SCP-publicatie. 